\title{
Knowledge about health service waste among health professionals in a municipality in central Tocantins state, Brazil
}

\author{
Conhecimento sobre resíduos de serviços de saúde entre profissionais na área da saúde de um \\ município da região central do estado do Tocantins, Brasil \\ Conocimiento sobre desechos de servicios de salud entre profesionales de la salud en un municipio \\ de la región central del estado de Tocantins, Brasil
}

\author{
Reobbe Aguiar Pereira \\ ORCID: https://orcid.org/0000-0003-2578-2611 \\ Faculdade Guaraí, Brasil \\ E-mail: enfreobbe@gmail.com \\ Dora Inés Kozusny-Andreani \\ ORCID: https://orcid.org/0000-0001-8518-0984 \\ Universidade Brasil, Brasil \\ E-mail: doraines@terra.com.br
}

\begin{abstract}
The objective of this work was to evaluate the knowledge about the management of health service waste among the professionals of the Basic Health Units of a municipality in the central region of the State of Tocantins, Brazil. It is a descriptive, exploratory study, with a quali-quantitative approach. The interviews were carried out with 89 health workers, being constituted a sample of 26 (29\%) nurses, odontologists and doctors, and 63 (71\%), professionals with high school education (community health agents, nursing technicians and oral health technicians). Among the workers with higher education $25(96.1 \%)$ interviewed correctly conceptualized the RSS, thus demonstrating knowledge on the subject, however, among the workers with secondary education 48 (76.1\%) gave an assertive response, drawing attention in this group the fact that $15(23.8 \%)$ did not answer the question correctly. Waste from health services is still understood as hospital waste by most questionnaires and the perforating ones are the most mentioned.
\end{abstract}

Keywords: Nursing; Practices; Knowledge.

\section{Resumo}

O presente trabalho teve o objetivo avaliar o conhecimento acerca do gerenciamento de resíduos de serviço de saúde entre os profissionais das Unidades Básicas de Saúde de um município da região central do Estado do Tocantins, Brasil. Trata-se um estudo do tipo descritivo, exploratório, com abordagem quali-quantitativa. As entrevistas foram realizadas com 89 trabalhadores de saúde, sendo constituída amostra de 26 (29\%) profissionais enfermeiros, odontólogos e médicos, e $63(71 \%)$, profissionais com ensino médio (agentes comunitários de saúde, técnicos em enfermagem e técnicos em saúde bucal). Entre os trabalhadores com ensino superior $25(96,1 \%)$ entrevistados conceituaram corretamente os RSS, demonstrando assim conhecimento sobre o assunto, no entanto, entre os trabalhadores com ensino médio $48(76,1 \%)$ deram uma resposta assertiva, chamando atenção nesse grupo o fato de que $15(23,8 \%)$ não responderam corretamente a questão. Os resíduos de serviços de saúde ainda são compreendidos como lixo hospitalar pela maior parte dos questionários e os perfurocortantes são os mais mencionados.

Palavras-chave: Enfermagem; Práticas; Saberes.

\section{Resumen}

Este estudio tuvo como objetivo evaluar el conocimiento sobre la gestión de residuos de servicios de salud entre los profesionales de las Unidades Básicas de Salud de una ciudad de la región central del Estado de Tocantins, Brasil. Se trata de un estudio descriptivo, exploratorio con enfoque cualitativo y cuantitativo. Las entrevistas se realizaron con 89 trabajadores de la salud, conformando una muestra de 26 (29\%) enfermeros profesionales, dentistas y médicos, y 63 (71\%), profesionales con educación secundaria (agentes comunitarios de salud, técnicos de enfermería y técnicos de salud oral). Entre los trabajadores con educación superior, 25 (96,1\%) entrevistaron correctamente conceptualizado RSS, demostrando así conocimiento sobre el tema, sin embargo, entre los trabajadores con educación secundaria 48 $(76,1 \%)$ dieron una respuesta asertiva, llamando la atención en este grupo el hecho de que $15(23,8 \%)$ no respondieron correctamente la pregunta. La mayoría de los cuestionarios todavía entienden los desechos de los servicios de salud como desechos hospitalarios y los objetos punzantes son los más mencionados. 
Palabras clave: Enfermería; Prácticas; Conocimiento.

\section{Introduction}

Health Services Residues (RSS) are generally considered only those originated from medical, dental, laboratory, pharmaceutical and teaching and research institutions in the health or veterinary area, among others. That is why the RSS are often called "hospital waste". RSS, despite representing a small portion of the total waste generated in a community, are potential sources of disease spread because they present an additional risk to health services professionals and the community in general, when improperly managed (Silva \& Hoppe, 2005).

The correct management of waste is of paramount importance both for the occupational safety of the professionals who handle it, and for public health in preserving the environment. The inadequate handling in the handling processes (segregation, conditioning, collection, storage, transportation, treatment, destination and final environmentally adequate disposal), brings a true contamination to the soil, water, atmosphere and in the proliferation of vectors and urban plagues, thus altering the environmental, physical and chemical factors.

Health care waste is of a heterogeneous nature. Therefore, it is of fundamental classification in the segregation of these types of waste. RSS are regulated through laws and technical standards. Having the existence of the Collegiate Directory Resolution (RDC) nº 306/2004 of the National Agency of Sanitary Vigilance (ANVISA), Resolution $n^{\circ}$ 358/2005 of the National Council of the Environment (CONAMA) and more recently the ANVISA Resolution n 222 of March 2018.

It is important to detach that previously RDC $n^{\circ} 306 / 2004$ disposes about the Management of Residues of Health Services (GRSS) and classifies the RSS in five groups (A, B, C, D, E), being maintained by ANVISA Resolution n 222/2018.

They fall into group A - waste with the possible presence of biological agents; group B - waste containing chemical substances that may present a risk to public health or the environment; group $\mathrm{C}$ - any material resulting from human activities that contains radionuclides; group D - waste that does not present a biological, chemical or radiological risk to health or the environment, and may be equated to household waste; and group E - perforating or scarifying materials, such as: razor blades, needles, scalps, glass ampoules, drills, endodontic files, diamond tips, scalpel blades, lancets, and other similar materials (Brazil, 2004).

Resolution 358 of CONAMA, determines that the legal responsible for the generating establishment will be responsible for the management of its waste from generation to final environmentally appropriate disposal (Brazil, 2005).

The Health Services Waste Management Plan (PGRSS) should guide the professionals of health institutions as to the routines to be adopted in the various stages of waste management from the destination of these materials to their final disposal. Define the internal and external collection flow of the RSS, the forwarding for the sterilization or crushing process and organization of the number of collections needed for each unit (Santos \& Souza, 2012).

In view of this, the awareness and continued education of professionals with the care of segregation of waste generated during its handling in the health environment is also of great relevance in providing a broader view of current environmental issues, by arousing interest and encouraging their participation in environmental quality programs at the hospital unit.

It is worth remembering that 2004 ANVISA published Resolution RDC n 306/2004, where it determined that training programs with the human resources sector should be part of the PGRSS. Personnel directly involved with waste management should be trained at the time of their admission and kept under continuous education for waste management activities, including their responsibility for personal hygiene, materials and environments (Brazil, 2004).

More recently in 2018 ANVISA published Resolution RDC n 222/2018 to regulate the "Good Practices in Health Services Waste Management". With this, it is expected that this normatization of good practices of health services residues 
management will be minimized in what concerns human and animal health in the country, as well as in the protection of the environment and renewable natural resources.

Therefore, hospital waste represents a major public health and environmental problem in Brazil, within health institutions there are still wrong practices regarding the steps used for RSS.

According to Nóbrega (2012), the inappropriate disposal of solid hospital waste, resulting from the action of biological, physical, chemical, radiological, household or drilling agents has produced enviro/nmental liabilities capable of compromising the natural resources and quality of life of current and future generations. Thus, this research aims to evaluate the knowledge about the GRSS among the professionals of the Basic Health Units of a municipality in the central region of the State of Tocantins.

\section{Methodology}

It is a descriptive, exploratory study, with a quality-quantitative approach, based on information collected with health professionals from the eight Basic Health Units (BHU) of a municipality in the central region of the State of Tocantins, with the urban population considered, in 2019, of 25.923 inhabitants (IBGE, 2019). The territorial area of 2.268,161 km² and demographic density of $10,23 \mathrm{inhab} / \mathrm{km}^{2}$. The municipality is part of the central region of the State of Tocantins, one of the eight health regions that make up the State Health Network, the Cerrado Region Tocantins Araguaia. This region is composed of 23 municipalities Arapoema, Bandeirante, Bernardo Sayão, Palmeirante, Colinas, Pequizeiro, Juarina, Itapiratins, Brasilândia, Couto Magalhães, Itaporã, Presidente Kennedy, Tupiratins, Colméia, Goianorte, Tupirama, Itacajá, Santa Maria, Recursolândia, Bom Jesus, Centenário and Pedro Afonso, totaling a population of 146.205 inhabitants (Tocantins, 2018).

The quali-quantitative character, according to Pereira et al., (2018), refers to the research that is found in measurements in quantitative studies or interviews and questionnaires in qualitative studies or quali-quantitative studies in which the numerical results are complemented by qualitative results.

The Basic Health Unit is composed by a staff of 141 workers, being: 32 professionals with higher education and 109 professionals in high school. However, the sample of this survey was composed of 89 workers that make up the staff of the eight Basic Health Units, distributed as follows:

Group I - professional with Higher Education: 26 workers (Nurses, Odontologists and Physicians);

Group II - Professional with High School: 63 workers (Community Health Agents, Nursing Technicians and Oral Health Technicians). The study was carried out according to the ethical principles of research with human beings, recommended in Resolution $n^{\circ} 466 / 2012$ of the National Health Council (Brazil, 2012). The research project was duly submitted to the Committee of Ethics in Research of the University of Brazil, São Paulo - SP, and obtained approval under opinion $\mathrm{n}^{\circ}$ 3.975.381.

For data analysis, Bardin's thematic content technique was used in the data obtained through the questionnaires (Bardin, 2011). In this sense, the four categories of thematic analysis were developed:

- Category 1 - Knowledge and conceptualization of Health Services Waste.

- Category 2 - Place of acquisition of knowledge about Health Services Waste.

- Category 3 - The relevance of the adequate management of Health Services Waste.

- $\quad$ Category 4 - Difficulties and Facilities for waste management.

In order to maintain the anonymity of the answers to the questionnaires, the professionals are identified as: Professional with Higher Education (PES), and Professional with Secondary Education (PEM), followed by the numerical order 01, 02, 03, 04, successively, which were identified in the data collection instrument. 


\section{Results and Discussion}

The questionnaires were applied to 89 health professionals, with a sample of 26 (29\%) professionals with higher education, and $63(71 \%)$ by high school professionals. The questionnaire followed a pre-established script, as described in the methodology.

Among the medium level 28 workers $(44,4 \%)$, there were no answers to the open questions regarding the concept of RSS, a place where they acquired understanding about RSS, the relevance of proper management, and the difficulties and facilities in waste management, among those who did not answer the open questions, there were answers only to the closed "yes" or "no" questions.

In the question about "Do you have knowledge about Health Services Waste Management?", among the interviewees of medium level $03(4,7 \%)$, they did not answer the question. It is important to highlight that in the question "Does the institution you work performs trainings or training on this subject?" the workers of higher level were almost unanimous 23 (88,4\%) in the answer to the "no", and among the workers of medium level $51(80,9 \%)$ interviewed also said "no" in their answers (Chart 1).

Chart 1. Health professionals' knowledge on health services waste.

\begin{tabular}{|c|c|c|c|c|c|c|c|c|c|c|c|c|}
\hline & \multicolumn{6}{|c|}{ Superior level workers } & \multicolumn{6}{|c|}{ Medium-level workers } \\
\hline & \multicolumn{2}{|c|}{ Yes } & \multicolumn{2}{|l|}{ No } & \multicolumn{2}{|c|}{ No answer } & \multicolumn{2}{|c|}{ Yes } & \multicolumn{2}{|c|}{ No } & \multicolumn{2}{|c|}{ No answer } \\
\hline & $\mathbf{N}^{\mathbf{o}}$ & $\%$ & $\mathbf{N}^{\mathbf{0}}$ & $\%$ & $\mathbf{N}^{\mathbf{0}}$ & $\%$ & $\mathbf{N}^{\mathbf{0}}$ & $\%$ & $\mathbf{N}^{\mathbf{o}}$ & $\%$ & $\mathbf{N}^{\mathbf{0}}$ & $\%$ \\
\hline $\begin{array}{l}\text { Do you know what } \\
\text { RSS is? }\end{array}$ & 25 & 96,1 & 01 & 3,8 & 00 & - & 48 & 76,1 & 15 & 23,8 & 00 & - \\
\hline $\begin{array}{l}\text { Does the institution } \\
\text { you work with carry } \\
\text { out training or } \\
\text { capacity building on } \\
\text { this topic? }\end{array}$ & 03 & 11,5 & 23 & 88,4 & 00 & - & 12 & 19,1 & 51 & 80,9 & 00 & - \\
\hline $\begin{array}{lr}\text { Do you } & \text { have } \\
\text { knowledge } & \text { about } \\
\text { RSS } & \text { Management? }\end{array}$ & 13 & $50 \%$ & 13 & $50 \%$ & 00 & - & 20 & 31,7 & 43 & 68,2 & 03 & 4,7 \\
\hline
\end{tabular}

Source: Authors (2019).

Among the workers with higher education $25(96,1 \%)$ interviewed correctly conceptualized the RSS, thus demonstrating knowledge on the subject, however, among the workers with secondary education $48(76,1 \%)$ gave an assertive response, draws attention in this group the fact that $15(23,8 \%)$ did not answer the question correctly. Regarding the questioning whether the work institution of the interviewees conducts training or trainings on Health Services Residues, $23(88,4 \%)$ of the workers with higher education, and $51(80,9 \%)$ of the workers with high education said "no" in their answers. Other data on health professionals' knowledge about RSS are described in Box 02. 
Chart 2. Health professionals' knowledge about RSS.

\begin{tabular}{|c|c|c|c|c|c|c|c|c|}
\hline \multirow{3}{*}{ Knowledge about RSS } & \multicolumn{4}{|c|}{ Higher Education } & \multicolumn{4}{|c|}{ High School } \\
\hline & \multicolumn{2}{|c|}{$\begin{array}{l}\text { The right } \\
\text { answer }\end{array}$} & \multicolumn{2}{|c|}{$\begin{array}{l}\text { Wrong } \\
\text { answer }\end{array}$} & \multicolumn{2}{|c|}{$\begin{array}{l}\text { The right } \\
\text { answer }\end{array}$} & \multicolumn{2}{|c|}{$\begin{array}{l}\text { Wrong } \\
\text { answer }\end{array}$} \\
\hline & $\mathbf{N}^{\mathbf{0}}$ & $\%$ & $\mathbf{N}^{\mathbf{o}}$ & $\%$ & $\mathbf{N}^{\mathbf{0}}$ & $\%$ & $\mathbf{N}^{\mathbf{0}}$ & $\%$ \\
\hline $\begin{array}{l}\text { Knowledge and Conceptualization of } \\
\text { Health Services Waste }\end{array}$ & 25 & 96,1 & 01 & 3,8 & 48 & 76,1 & 15 & 23,8 \\
\hline $\begin{array}{l}\text { The work institution conducts training or } \\
\text { training on Waste from Health Services }\end{array}$ & 03 & 11,5 & 23 & 88,4 & 12 & 19,1 & 51 & 80,9 \\
\hline $\begin{array}{l}\text { Place of acquisition of knowledge about } \\
\text { Health Services Waste }\end{array}$ & 25 & 96,1 & 01 & 3,8 & 36 & 57,1 & 27 & 42,8 \\
\hline $\begin{array}{l}\text { Knowledge about Health Services Waste } \\
\text { Management }\end{array}$ & 13 & 50,0 & 13 & 50,0 & 20 & 31,7 & 46 & 73,0 \\
\hline $\begin{array}{l}\text { The relevance of proper management of } \\
\text { Health Services Waste }\end{array}$ & 25 & 96,1 & 01 & 3,8 & 26 & 41,2 & 37 & 58,7 \\
\hline $\begin{array}{l}\text { Difficulties and Facilities for Waste } \\
\text { Management }\end{array}$ & 20 & 76,9 & 06 & 26,0 & 21 & 33,3 & 42 & 66,6 \\
\hline
\end{tabular}

Source: Aauthors (2019).

\section{Category 1. Knowledge and conceptualization of Health Services Waste:}

The questionnaires showed that professionals with higher education have knowledge about what RSS are, 25 (96,1\%) of the professionals answered the question correctly. Only 01 (3,8\%) did not answer correctly, demonstrating confusion and ignorance in the concept.

In fact, the simple knowledge of what RSS is promotes among professionals a more committed action in "meeting the requirements of the laws that figure in the workplace, more integrity, able to meet clearly and efficiently the needs of our environment" (Camargo \& Melo, 2017, p. 635).

In this sense, Gomes (2015) states that the knowledge by professionals about what RSS are and the harm they cause to health and the environment is one of the first steps to awaken concern about the environmental issue involved in this process. This author verified that most of the professionals are aware about the production and correct administration of RSS.

Despite the positive results of this survey regarding the fact that UBS higher education workers in the municipality of central Tocantins State have knowledge about RSS, this is not the reality among most health workers.

The study conducted by Camargo and Melo (2017) states that most of the professionals researched at UBS and outpatient centers in the municipality of Sorocaba do not know what RSS is and, in some cases, even know what it is, but can not explain about the correct handling, proper disposal or even the importance to the environment as a whole. These authors verified that $60 \%$ of the professionals don't know the PGRSS and $40 \%$ know only superficially.

Silva et al., (2015) conducted a survey with staff from a public hospital, in which they were asked to identify the three main symbols of the Waste Groups (A and E, B and C) of RSS. The results showed that 23,53\% of the employees answered incorrectly the identification of the "Figure E" that represents the waste of Group A and E, calling it "biological, infectious or perforating waste". In relation to Group B, $46.80 \%$ were wrong, since they referred to this group as "poisonous", "something dangerous" or "radioactive". In the other symbols there were hits, but the majority of the respondents answered incorrectly. 
In a study carried out at UBS and Pronto Socorro Municipal in a city in the interior of Minas Gerais, the lack of knowledge in several aspects was identified, among those interviewed 50\% did not know the PGRSS; 83\% did not know the pertinent legislation; $87 \%$ did not know the health waste groups; $4 \%$ did not know the consequences of incorrect handling of RSS; 87\% did not know the waste groups; 96\% did not know the symbols that represent the health waste; and 8\% did not know which are the contributions of the PGRSS (Borges et al., 2017).

It was verified during the application of the questionnaires carried out in this survey that some participants use the word garbage as a synonym for RSS or as everything that in its concept needs to be discarded, because it is no longer useful, however for nature garbage is part of inert natural processes, and the concept of the same is a human invention.

The incorrect conceptualization about waste is associated in part with the difficulty in determining when an object becomes or ceases to be a waste. In this sense, waste is defined as substances or objects, which are discarded, or are intended to be discarded, or must be discarded by the legal provisions established in national legislation.

The lack of knowledge about RSS by some health workers highlighted the need to train the collaborators of the institutions. The lack of knowledge in relation to PGRSS is associated to the inexistence of capacity building or training (Borges et al., 2017). According to Coswosk et al., (2018) training and capacity building are important for the dissemination of correct information that are fundamental for professionals to perceive that they are responsible for waste generation in their work activities.

\section{Category 2. Place of acquisition of knowledge about Health Services Waste:}

The concern with RSS should cover both field professionals and those in training, that is, future professionals. Regarding the above, there are studies that emphasize the importance of the Health Services Waste approach in the health undergraduate courses in promoting the subjects' awareness, besides diagnosing failures in the initial training, mainly because the institution does not have a systemic view on the subject (Camargo \& Melo, 2017).

Regarding the place of acquisition of knowledge about RSS, the interviewees from higher education manifested that they got in touch with the subject at college, university or during graduation. However, some professionals reported that they acquired the concept in the workplace, through personal research on the subject in books and ANVISA's website. While high school participants responded that they acquired understanding about RSS in technical courses, internet and day to day hospital environment.

Other spaces were also cited as places where those interviewed with high school or high school acquired understanding about RSS, such as: National Health Foundation, State Health Secretariat and media reports.

Although higher education workers report that they have acquired knowledge on the subject in the academic environment, this is not a reality in the health area. According to Coswosk et al., (2018), it is possible that the lack of insertion of the RSS theme in health courses and the lack of knowledge of the existing legislation are a justification for the large amount of waste produced and the neglect for the lack of treatment of them. It is necessary to reflect on a new consciousness of responsibility with ways to perceive the reality that coexists in the world, since it is individual choices that emerge the future collectivity. The environment, despite being collective, is the product of individualities.

According to Bento et al., (2017), there is a gap in the production of knowledge on the topic of RSS, and it can be observed that this topic has been little addressed in academic circles and in the daily practices of health professionals. The researches highlight the need to instrumentalize these health professionals to the adequate management of the RSS.

The deficiency of an unskilled labor force is associated with the technical education for which health professional training courses are submitted, so Coswosk et al., (2018) refers to the continuous need for education not only in the academic environment, but also in other non-school spaces, such as health care environments. 
A training needs to involve the pertinent subjects of each sector in relation to the handling of RSS, remembering that the adequate training increases the efficiency of the work, decreases the operational costs and reduces the rates of work accidents (Sales et al., 2009).

\section{Category 3. The relevance of proper management of Health Services Waste:}

In the health units, whether public or private, it is still a great challenge to manage RSS. The agency that regulates and guides the elaboration of the Health Services Waste Management Plan (PGRSS) is the National Health Surveillance Agency (ANVISA), through the Collegiate Directory Resolution (RDC) $n^{\circ} 306 / 2004$, in this each institution that generates RSS must elaborate a plan for the management, segregation, conditioning, collection, storage, transport and final disposal of the produced residues (Mahler \& Moura, 2017).

About the relevance of the adequate management of the RSS 25 (96,1\%, Chart 2) of the higher education professionals highlighted being important, explaining mainly the relevance to the environment, social, public health and sanitary, being necessary to carry out adequate waste disposal management, but for that it is important to follow all the stages: segregation, conditioning, collection, storage, transportation, treatment and final environmentally adequate disposal. In this research it was verified that a worker $(3,8 \%)$ was not able to define correctly the importance of the adequate management of the RSS.

The results obtained showed that $37(58,7 \%)$ high school workers did not answer correctly the question about the relevance of proper management of the RSS, many evidenced the lack of knowledge. While $26(41,2 \%)$ presented knowledge on the subject, following the line of a more ecological thinking, with clear concern for the environment and as a consequence of public health.

Inadequate management of HSR causes numerous risks, including accidental needle injury, which can cause hepatitis $\mathrm{B}$ and hepatitis $\mathrm{C}$ and HIV infection. Therefore, inadequate management of HSR potentially exposes health professionals, waste handlers, patients and the community in general to infection, toxic effects, injuries and risks that pollute the environment. It is essential that all waste materials are segregated at the point of generation, properly treated and safely disposed of (Who, 2014).

Every year, an estimated 16 billion injections are administered worldwide, but not all needles and syringes are correctly disposed of after use. Health care waste contains potentially harmful micro-organisms that can infect hospitalized patients, healthcare professionals and the general public. Other potential infectious risks may include the spread of drug-resistant microorganisms from healthcare facilities into the environment (Who, 2018).

High-income countries generate, on average, up to $0,5 \mathrm{~kg}$ of hazardous waste per hospital bed per day, while lowincome countries generate $0,2 \mathrm{~kg}$ on average. However, health care waste is generally not separated into hazardous or nonhazardous waste in low-income countries, making the actual amount of hazardous waste much greater (Andre, Veiga \& Takayanagui, 2016).

In developing countries, additional risks occur due to the elimination of RSS in common waste disposal sites, as well as the manual sorting of hazardous waste in health facilities. These practices are common in many regions of the world. Waste handlers are at immediate risk of needle-stick injuries and exposure to toxic or infectious materials (Gouveia, 2012; Boreli, Godoy \& Kozusny-Andreani, 2018).

Lack of awareness of health risks related to wasteful health care, inadequate training in proper waste management, lack of waste management and disposal systems, insufficient human and financial resources, and low priority given to the topic are the most common problems related to RSS (Gouveia, 2012).

An essential issue to be discussed is the clear attribution of responsibility for the handling and disposal of waste. According to the "polluter pays" principle, the responsibility lies with the producer of the waste, usually the health service 
provider or the establishment involved in related activities. To achieve safe and sustainable management of health care waste and financial analyses should include all disposal costs (Who, 2018).

\section{Category 4. Difficulties and Facilities for waste management:}

This category expresses the facilities and difficulties identified by professionals with higher education in the management of health services waste in the health institution. It is worth mentioning that the answers of factors that would facilitate match with the answers of factors that hinder waste management. Factors such as lack of adequate container, lack of capacity building or lack of knowledge, lack of transportation and other aggravating factors were the main difficulties cited by $20(76,9 \%)$ of workers with higher education (Chart 2).

The lack of training and RSS management programs was a difficulty cited by professionals, however, an easy factor is the openness to knowledge which may contribute for some of the participants to mention that they have no difficulty in handling waste.

In continuity, an important obstacle to be developed in the activities about the management of the RSS is the understanding of the professionals for the premise that all health environment produces waste. Although UBS contributes with a small portion of hazardous waste, they provide basic services that do not require hospitalization (medical consultations, orientation, inhalations, dressings, immunizations, application of injectable medications, collection of samples for laboratory exams, dental treatment and provision of basic medication), they are also called on to adequately manage their waste, according to the rules in force in the country (Moreira \& Günther, 2016).

Among the responses from high school workers is the fact that $42(66,6)$ did not respond or responded inadequately to the question. However, 21 (33,3\%) professionals expressed that they do not feel difficulty, because in the agency they work they have specific places to separate waste, but it would be necessary to pay more attention to training programs on the subject.

The struggle for an effective and concrete policy for the correct management of waste is far from reaching its apex. As we can observe the so called "small generators" is the case of the Basic Health Units, which is the entrance door to the Public Health System - SUS, still difficulties in the practice of what is recommended by the legislation, many times by the manager's carelessness, also by the inspection failure. Although the rules and legislation in force are broad and detailed, it calls attention to the fact that the players involved in the development of these public policies at municipal level are still not awake on waste management issues, mainly concerning health services waste (Ramos, 2013).

\section{Conclusion}

Based on the results of this study, the following conclusions were drawn.

The general awareness among UBS health professionals regarding RSS was higher among higher education workers $(96,1 \%)$ than high school $(76,1 \%)$. What should be inferred is that the awareness about RSS in these health institutions can and should be improved through training and capacity building, especially on waste segregation, since higher education workers $(88,4 \%)$ and high school $(80,9 \%)$ said that the institution where they work does not have such action.

Therefore, high school workers should receive training, since they are the least aware of the subject. These professionals are very often required to perform a variety of roles in different configurations, so they need to have solid knowledge and safe practices that minimize the risks that promote a safe handling of RSS.

The UBS is recommended to have a manager or person in charge especially to dedicate themselves to the discussion of the subject and orientation in the institution, including creating a work schedule on waste management.

Another important result is the lack of knowledge of PGRSS, or the UBS do not have or workers really do not have access. This question was left unanswered in many questionnaires, and when it was answered there was confusion in the answers. 
Health care waste is still understood as hospital waste by most interviewees and sharp punctures are the most mentioned as an example.

It is suggested to continue studies, training and training regarding waste management among professionals directly involved in the management of SSR, so that there is assistance in the development and effectiveness of health service waste management.

\section{References}

Andre, S. C. S., Veiga, T. B., \& Takayanagui, A. M. M. (2016). Generation of Health Services Waste in hospitals in the city of Ribeirão Preto (SP), Brazil. Eng. Sanit. Ambient. Rio de Janeiro, 21(1), 123-130.

Bardin, L. (2011). Content Analysis. Editions 70.

Bento, D., et al., (2017). The Management of Health Service Waste from the Perspective of Nursing Professionals. Text Contexto Enferm, 26(1).

Borges, N. C. F., et al., (2017). Health Services Waste Management Plans: an analysis of the knowledge and qualification of employees. Hygeia, 13(24), 14-23.

Boreli, D., Godoy, S. R., \& Kozusny-Andreani, D. I. (2018). Management of infectious solid waste in a hospital unit. Nucleus, 15(1).

Brazil. (2004). Ministry of Health. National Health Surveillance Agency-ANVISA. Resolution RDC $N^{o} 306$, of December 7.

Brazil. (2018). Ministry of Health. National Health Surveillance Agency-ANVISA. Resolution RDC N 222 of March 28.

Brazil. (2005). Ministry of Health. National Environment Council-CONAMA. Resolution CONAMA Nº 358, of April 29.

Brazil. (2012). Ministry of Health. Ministry of Education. Instruction Manual - School Health Program. Brasília.

Brazil. (2006). Ministry of Health. National Health Surveillance Agency. Health Services Waste Management Manual / Ministry of Health, National Health Surveillance Agency. - Brasília: Ministry of Health. 182 p.

Camargo, Â. R., \& Melo, I. B. N. (2017). The professional perception about the management of health services waste in basic and ambulatory units in a municipality of the Metropolitan Region of Sorocaba, SP, Brazil. Mundo saúde (Impr.), 41(4), 633-643.

Coswosk, É. D., et., (2018). Continuing Education for the Health Professional in the Management of Health Waste. RBAC, 50(3), 288-96.

Gomes, A. M. P. (2015). Socio-environmental responsibility: knowledge of health professionals on waste management in public service. 2015.64 f. Dissertation (Masters in Preventive and Social Dentistry) - Faculdade de Odontologia de Araçatuba, Universidade Estadual Paulista, Araçatuba.

Gouveia, N. (2012). Urban solid waste: socio-environmental impacts and sustainable management perspective with social inclusion. Ciência \& saúde coletiva, $17,1503-1510$.

IBGE. (2019). Brazilian Institute of Geography and Statistics. Brazil/Tocantins/Guaraí.

Mahler, C. F., \& Moura, L. L. (2017). Waste from Health Services (RSS): A qualitative approach. RISTI-Iberian Journal of Information Systems and Technologies, n. 23, p. 46-60.

Moreira, A. M. M., \& Günther, W. M. R. (2016). Solid waste management in primary healthcare centers: application of a facilitation tool. Revista latinoamericana de enfermagem, vol. 24.

Nóbrega, P. M. (2012). Health Services Solid Waste Management: a case study / Architect Tecn Mil Paoletta Mantuano da Nóbrega. - Rio de Janeiro: ESG.

Pereira, A. S. et al., (2018). Metodologia da pesquisa científica. UFSM. https://repositorio.ufsm.br/bitstream/handle/1/15824/Lic_Computacao_MetodologiaPesquisa-Cientifica.pdf?sequence=1.

Ramos, D. A. B. (2013). Impasses and difficulties in the management of health services waste in basic health units: case study in the municipality of Araçatuba - SP. 86 f. Dissertation (Masters) - Escola Nacional de Saúde Pública Sergio Arouca, Rio de Janeiro.

Santos, M. A., \& Souza, A. O. (2012). Knowledge of nurses of the Family Health Strategy about health services residues. Rev Bras Enferm, 65(4).

Silva, M. S., et al., (2015). Knowledge of professionals on waste management in a Midwest hospital. Revista Meio Ambiente e Sustentabilidade, 9(4), $262-281$.

Silva, C. E., \& Hoppe, A. E. (2005). Diagnostic of Health Services Waste in the Interior of Rio Grande do Sul. Eng. sanit. Ambient. 10(2), 146-151.

Tocantins. State Secretariat of. SESAU. (2018). Government of the State of Tocantins.

Sales, C. C. L., et al., (2009). Management of solid waste from health services: aspects of internal management in the municipality of Marituba, Pará, Brazil. Ciênc. saúde coletiva, 14(6), 2231-2238.

WHO. World Health Organization. (2018). Health-care waste. Geneva.

WHO. World Health Organization. (2014). Safe management of wastes from health-care activities / edited by Y. Chartier et al. (2nd ed.), 